\title{
Pengelolaan sampah berbasis masyarakat di era new normal (Pendampingan pengelolaan bank sampah Puri Berlian Kelurahan Air Putih di era normal)
}

\author{
Titi Antin ${ }^{1 *}$, Darusman $^{2}, \&$ Yefni $^{2}$ \\ ${ }^{1}$ Prodi Ilmu Komunikasi, UIN Sultan Syarif Kasim - Riau \\ ${ }^{2}$ Prodi Pengembangan Masyarakat Islam, UIN Sultan Syarif Kasim - Riau \\ *Titi.antin@uin-suska.ac.id
}

\begin{abstract}
Abstrak. Bank sampah Puri Berlian terletak di RT.04/RW.02 Kelurahan Air Putih Kecamatan Tampan. Berdasarkan hasil FGD (Focus Group Discussion) dengan pengelola bank sampah, dapat diidentifikasi beberapa permasalahan yaitu: bank sampah tidak aktif selama Pandemi Covid-19, sehingga sampah menumpuk di pihak nasabah, kurangnya literasi tentang sampah, sebagian besar nasabah belum memahami tentang dampak yang ditimbulkan oleh sampah serta bagaimana pengelolaan bank sampah. Tujuan yang akan dicapai adalah mengaktifkan kembali kegiatan bank sampah di masa new normal ini serta memberikan pemahaman tentang sampah secara umum kepada anggota. Metode yang digunakan adalah memberikan sosialisasi dan edukasi tentang manfaat bank sampah, membantu mengaktifkan kembali kegiatan bank sampah membuat perencanaan pengembangan bank sampah. Hasil dari kegiatan ini adalah kegiatan penabungan sampah kembali dilakukan secara bertahap, mempersuasi warga yang belum menjadi anggota untuk masuk menjadi nasabah, serta menjajaki pengembangan subunit bank minyak goreng bekas (minyak jelantah).
\end{abstract}

Kata kunci: bank sampah, pengelolaan sampah berbasis masyarakat, new normal.

\begin{abstract}
Puri Berlian waste bank is located in RT.04/RW.02 of Air Putih Village, Tampan District. Based on the FGD result (focus group discussion) with the waste bank management, several issues can be identified, namely: waste bank is inactive during the Covid-19 Pandemic that causes the piling of the customers wastes; lack of literacy regarding waste, most of the customers have yet to understand the impacts caused by waste as well as the management of waste banks. The goal to be achieved is re-activating the activity of the waste bank during this new normal era while providing the general knowledge about waste towards the members. The methods used for this study are giving socialization and education regarding the benefit of waste banks, supporting the reactivation of waste bank activities, and formulating the development plan for the waste bank. The results of this study show that the activity of waste storing is recommenced gradually, local people who have not become the member are persuaded to be the customer, and the development of a bank subunit of used cooking oil (minyak jelantah) is explored.
\end{abstract}

Keywords: waste bank, community-based waste management, new normal

To cite this article: Antin, T., Darusman., \& Yefni. 2020. Pengelolaan sampah berbasis masyarakat di era new normal (Pendampingan pengelolaan bank sampah Puri Berlian Kelurahan Air Putih di era normal). Unri Conference Series: Community Engagement 2: 329-334. https://doi.org/10.31258/unricsce.2.329-334

(C) 2020 Authors

Peer-review under responsibility of the organizing committee of Seminar Nasional Pemberdayaan Masyarakat 2020 


\section{PENDAHULUAN}

Selama pandemi Covid-19 kebijakan untuk tetap tinggal di rumah yang dikeluarkan pemerintah ternyata berdampak pada meningkatnya volume sampah pada skala rumah tangga serta limbah medis secara signifikan. Sebagaimana disampaikan oleh Melly Amelia (Manajer Kampanye YPBB) pengurangan sampah dari sektor komersial seperti restoran, pusat perbelanjaan dan pariwisata memang mengalami penurunan. Namun di sisi yang lain, terdapat peningkatan sampah rumah tangga karena perubahan pola konsumsi masyarakat pasca penerapan kebijakan kerja dari rumah dan pembatasan sosial. "Sebagian besar masyarakat membatasi diri dengan hanya melakukan aktivitas di rumah. Tetapi untuk memenuhi kebutuhan konsumsi mereka belanja secara daring dengan tren kenaikan berdasarkan data riset antara 27-36 persen. Akhirnya timbulan sampah seperti kemasan plastik sekali pakai mengalami peningkatan" sebagaimana disampaikannya pada situs berita lingkungan Mongabay (Suriyani, 2020)

Berdasarkan data statistik Dinas Lingkungan Hidup Kota Pekanbaru, menyebutkan bahwa volume timbulan sampah tahun 2018 mencapai 492,11 ton/hari. Dari jumlah tersebut, sampah yang mampu dikelola dan masuk ke di TPA (tempat pengolahan akhir sampah) Muara Fajar berjumlah 447,50 tin/hari, dan hanya sekitar 3 - 5 $\%$ sampah yang dikelola oleh masyarakat melalui konsep 3R (reduce, reuse, recycle) (Dinas LHK Pekanbaru, 2019). Jumlah ini tergolong kecil, menandakan bahwa partisipasi masyarakat cenderung rendah dalam mengelola sampah secara mandiri, Hal ini tentunya perlu menjadi perhatian semua pihak tidak saja pemerintah, karena mengelola sampah sejatinya menjadi tanggung jawab setiap individu sebagai produsen sampah (Afriadi et al., 2019). Dan kondisi ini tentunya diharapkan tidak mengurangi semangat dari kelompok pengelolaan sampah mandiri yang sudah aktif berjalan dalam bentuk kegiatan bank sampah, sudah sampah, maupun daur ulang sampah di tengah pandemic Covid-19 ini.

Pemberlakuan masa new normal membuat masyarakat kembali menata rutinitasnya dengan tetap memperhatikan protokol kesehatan. Salah satunya adalah mengelola sampah dengan cara memilah dan kemudian ditabung di bank sampah yang biasa dilakukan oleh Ibu-ibu nasabah Bank Sampah Puri Berlian RT.04/RW.02 Kelurahan Air Putih Kecamatan Kota Pekanbaru. Bank sampah Puri Berlian terletak di RT.04/RW.02 Kelurahan Air Putih Kecamatan Tampan Kota Pekanbaru. Kelurahan Air Putih merupakan salah satu kelurahan hasil pemekaran dari Kelurahan Simpang Baru Kecamatan Tampan dalam pemekaran wilayah Kota Pekanbaru pada tahun 2016. Jumlah penduduk Kelurahan Air Putih dalam proyeksi BPS tahun 2010-2020 sebanyak 24.569 jiwa dengan jumlah rumah tangga sebanyak 6.084. Jumlah RT di kelurahan Air Putih sebanyak 64 dan RW. 10 (BPS, 2020)

Terkait dengan keberadaan bank sampah Puri Berlian di Kelurahan Air Putih, bank sampah ini merupakan salah satu bank sampah unit dari bank sampah induk Bukit Hijau Berlian Kecamatan Tampan, dibentuk pada tahun 2018 dengan jumlah nasabah saat ini 43 orang. Bank sampah yang baru terbentuk, tentunya masih berbenah diri dan perlu didukung oleh sarana dan prasarana untuk menjadi lebih baik lagi, penambahan jumlah nasabah juga menjadi prioritas dalam pengembangannya.

Berdasarkan hasil focus group discussion dengan pengelola bank sampah, kondisi riil di lapangan menggambarkan bahwa terdapat beberapa permasalahan yang dapat diidentifikasi diantaranya yaitu:

a. Kurangnya kegiatan literasi tentang sampah kepada masyarakat dari pihak terkait.

b. Belum memiliki sarana dan prasarana seperti bangunan atau lahan untuk menampung sampah yang akan disetorkan ke bank sampah induk, karena saat ini kegiatan bank sampah masih menumpang pada bangunan pos ronda RT 04.

c. Peralatan pendukung seperti timbangan digital untuk menimbang sampah, gerobak untuk mengangkut sampah dari nasabah.

d. Terbatasnya sumber daya pengelola sampah seperti tenaga pemilah sampah.

e. Pada masa pandemi Covid-19 ini, bank sampah tidak beroperasi dikarenakan bank sampah induk pun untuk sementara tutup. Hal ini menyebabkan volume sampah pada level rumah tangga meningkat. Bank sampah yang tidak aktif dapat berdampak pada menurunnya semangat warga untuk memilih dan menggabungkan sampahnya di bank sampah. Hal ini akan berdampak pada keberlanjutan (sustainability) bank sampah.

Oleh karenanya kegiatan pengabdian masyarakat ini bertujuan untuk:

a. Mengedukasi warga tentang pentingnya mengelola sampah. Manfaat mengelola sampah tidak hanya pada aspek lingkungan tetapi juga pada aspek ekonomi dan sosial,

b. Mempersuasi warga untuk berpartisipasi menjadi nasabah bank sampah

c. Memberikan pendampingan pada pengelolaan bank sampah serta menjajaki pengembangan jaringan (networking) bank sampah dengan stakeholders lainnya. 
Sasaran kegiatan pengabdian masyarakat melalui pendampingan pengelolaan bank sampah di era new normal, adalah ibu-ibu pengelola bank sampah serta sasaran lebih luas adalah ibu-ibu warga di lingkungan Kelurahan Air Putih yang belum menjadi nasabah bank sampah. Sasaran kegiatan difokuskan kepada ibuibu, dengan pertimbangan bahwa ibu-ibu mempunyai peran yang dominan dalam kegiatan pengelolaan sampah ini. Sampah yang dimaksud adalah rumah tangga.

Tren volume sampah saat ini selalu mengalami kenaikan dari waktu ke waktu. Hal ini disebabkan oleh beberapa faktor, diantaranya yaitu: pola hidup masyarakat yang serba instan, perkembangan industri yang signifikan mendorong banyaknya limbah atau residu yang dihasilkan, faktor budaya masyarakat yang belum peduli terhadap sampah serta pengelolaan sampah yang tidak ramah lingkungan seperti membakar sampah, membuang sampah di jalan-jalan atau di lahan kosong.

Menurut Undang-Undang RI No. 18 tahun 2008 Tentang Pengelolaan Sampah, sampah didefinisikan sebagai sisa kegiatan sehari-hari manusia dan/atau proses alam yang berbentuk padat. Kamus Besar Bahasa Indonesia mendefinisikan sampah sebagai barang atau benda yang dibuang karena tidak terpakai lagi (Republik Indonesia, 2008). Sampah dapat dikelompokkan dalam beberapa jenis berdasarkan karakteristiknya (Suwenda, 2012), yaitu:

1. Sampah Anorganik, bersifat nonbiodegradable, yaitu sampah yang tidak dapat didegradasi atau diuraikan secara sempurna melalui proses biologi baik secara aerob maupun anaerob. Sampah jenis ini ada yang dapat diolah dan digunakan kembali karena memiliki nilai ekonomi, seperti plastic, kertas bekas, kain perca, styrofoam.

2. Sampah Organik, bersifat biodegradable, yaitu sampah yang dapat yaitu sampah yang dapat diuraikan secara sempurna melalui proses biologi baik secara aerob maupun anaerob, seperti yang berasal dari sampah sisa dapur, sisa-sisa sampah pertanian, dan lai-lain

Pada masyarakat perkotaan maupun perdesaan, komposisi sampah didominasi oleh sampah organik (sampah yang mudah terurai / biodegradable), sekitar 60\%-70\%) dari total volume sampah. Sementara sisanya berupa sampah anorganik. Sumber sampah tersebut berasal dari rumah tangga, areal pertanian, perkebunan, dan peternakan (Sucipto, 2012). Sementara ini, sebagian besar sampah yang dapat diolah ataupun yang ditabungkan di bank sampah masih berupa sampah anorganik, sedangkan sampah organik sebagian diolah menjadi kompos atau biogas secara mandiri oleh warga.

Menurut Iswanto (penggiat sampah di Daerah Istimewa Yogyakarta), pengelolaan sampah berbasis masyarakat atau dikenal juga dengan pengelolaan sampah mandiri, merupakan penanganan sampah yang direncanakan, dilaksanakan, dikembangkan dan dijaga kelangsungannya oleh suatu kelompok masyarakat/ komunitas seperti RT/RW/ kampung / dusun (Antin, 2019). Sedangkan Suwerda mengatakan pengelolaan sampah dengan sistem mandiri dan produktif adalah sistem pengelolaan sampah yang melibatkan peran serta masyarakat untuk bersama-sama mengelola sampah. Sistem ini menekankan kemandirian masyarakat dalam mengelola sampah yang dihasilkan, dan tidak harus selalu tergantung pada pemerintah (Suwenda, 2012).

Keberadaan pengelolaan sampah mandiri berbasis masyarakat seperti bank sampah atau sedekah sampah, menempatkan masyarakat sebagai pelaku utama (subyek) dan mempuny ai tanggung jawab mengelola sampah pada skala komunitas. Kesadaran untuk mengelola sampah secara mandiri perlu terus dikembangkan melalui pendekatan-pendekatan komunikasi persuasif kepada masyarakat, karena suatu program atau inovasi dalam bentuk apapun, dapat berjalan jika ada komunikasi yang yang baik. Zulkarimein menegaskan bahwa masuknya suatu inovasi ke tengah suatu sistem sosial terutama karena terjadinya komunikasi antar anggota suatu masyarakat. Komunikasi merupakan faktor yang penting untuk terjadinya suatu perubahan sosial (Nasution, 2002).

Berdasarkan hasil penelitian Antin, menjelaskan bahwa masyarakat sebagai suatu sistem mampu mengembangkan dan mendistribusikan pengetahuan, kreativitas, gagasan-gagasan dalam pengelolaan sampah. Hal itu perlu didukung oleh berbagai aspek aar terjadi sustainability (keberlanjutan dari kegiatan bank sampah tersebut, seperti melibatkan pemerintah daerah, pihak swasta, maupun stakeholders lainnya. Pengelolaan sampah berbasis masyarakat dapat berupa kelompok bank sampah, sedekah sampah, daur ulang sampah atau TPS 3R dalam kegiatan ini difokuskan pada kelompok bank sampah (Antin, 2019).

Aktivitas di bank sampah hampir menyerupai aktivitas di bank konvensional, yaitu adanya kegiatan menabung dan menarik tabungan melalui teller. Pengertian bank sampah menurut Suwerda adalah suatu tempat di mana terjadi kegiatan pelayanan terhadap penabung sampah (nasabah) yang dilakukan oleh teller bank sampah (Suwenda, 2012). Ada tiga pihak yang terlibat dalam kegiatan bank sampah yaitu; penabung, teller, dan pengepul. 
Penabung; adalah warga baik secara individu ataupun kelompok yang menjadi anggota dibuktikan dengan buku tabungan dan nomor rekening serta berhak atas hasil tabungan sampahnya. Teller; adalah petugas bank sampah yang bertugas melayani penabung sampah, yaitu menimbang berat ampah, melabeli sampah, mencatat dalam buku induk, dan berkomunikasi dengan pengepul. Pengepul; adalah individu atau lembaga yang termasuk dalam sistem pengelolaan sampah dengan tabungan sampah dan menilai secara ekonomi setiap sampah yang ditabung oleh warga baik individu maupun komunal.

\section{METODE PENERAPAN}

Dalam rangka pencapaian tujuan yang telah ditetapkan dalam kegiatan ini, maka metode yang digunakan untuk menjawab permasalahan di atas, yaitu dilakukan dengan cara: a) melakukan sosialisasi dan edukasi tentang pengelolaan sampah kepada pengelola dan nasabah bank sampah, b) memberikan pendampingan pada Bank Sampah Puri Berlian terutama pada manajemen bank sampah, c) memperluas networking pengelolaan sampah dengan menjajaki kegiatan bank sampah minyak jelantah. Di mana selama ini minyak jelantah di buang begitu saja belum dimanfaatkan ataupun dijual ke pengepul. Padahal minyak jelantah yang dibuang secara langsung ke tanah atau ke sungai akan berdampak negatif dan menimbulkan pencemaran.

\section{HASIL DAN KETERCAPAIAN SASARAN}

Suatu kegiatan harus dapat diukur untuk menentukan berhasil atau tidaknya suatu kegiatan. Adapun alat ukur ketercapaian kegiatan ini adalah:

Aktivitas bank sampah di era new normal sudah dimulai kembali sebagaimana dapat dilihat pada gambar 1 .

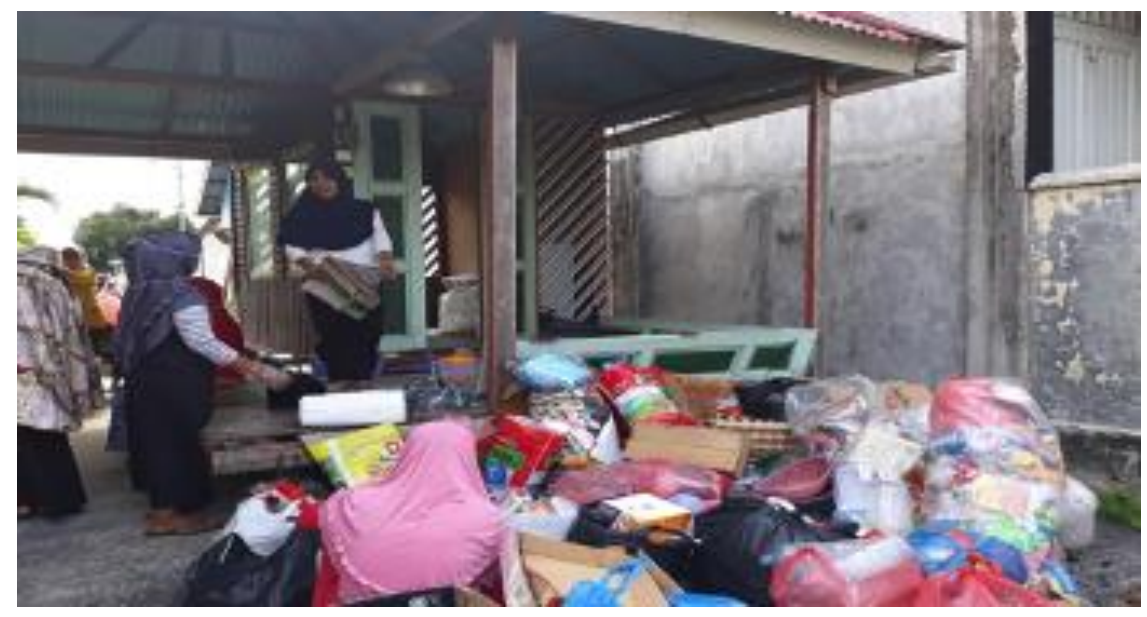

Gambar 1. Sampah yang telah ditimbang dikumpulkan kemudian dilakukan pemilahan oleh tenaga pemilah.

Kegiatan pengumpulan sampah dilakukan oleh ibu-ibu pengelola bank sampah bertempat di Pos Kamling RT.04. Sebagaimana diketahui bahwa bank sampah Puri Berlian belum mempunyai tempat permanen sehingga kegiatan bank sampah menumpang di pos kamling RT.04.

a. Membuka kembali kegiatan tabungan sampah yang dilakukan 2 minggu 1 kali, dimana selama masa pembatasan sosial berskala besar, kegiatan ini mengalami kevakuman.

b. Perencanaan program bank minyak jelantah

c. Menambah keterampilan ibu-ibu untuk mendaur ulang sampah anorganik, terutama plastik menjadi barangbarang yang layak pakai dan layak jual.

d. Bank Sampah Puri Berlian yang berdiri tahun 2018 tergolong bank sampah yang masih baru dan memerlukan pembinaan untuk menjaga keberlanjutannya (sustainability).

Hasil dan ketercapaian sasaran dari kegiatan pengabdian masyarakat ini adalah; a) sosialisasi dan edukasi yang diberikan kepada pengurus dan warga, menunjukkan bahwa adanya peningkatan pengetahuan tentang sampah, karena sebagian besar ibu-ibu tidak mengetahui bahaya sampah secara lebih rinci, misalnya tentang bahaya penggunaan styrofoam sebagai wadah makanan bagi kesehatan, tingginya volume sampah baik secara nasional maupun lokal, pengetahuan tentang masa terurainya sampah. b) Nasabah bank sampah sudah mulai 
merasakan manfaatnya menabung sampah secara ekonomi, dengan rajin menabung sampah maka jumlah tabungan akan terus meningkat, sebagaimana dalam gambar 2 berikut ini;

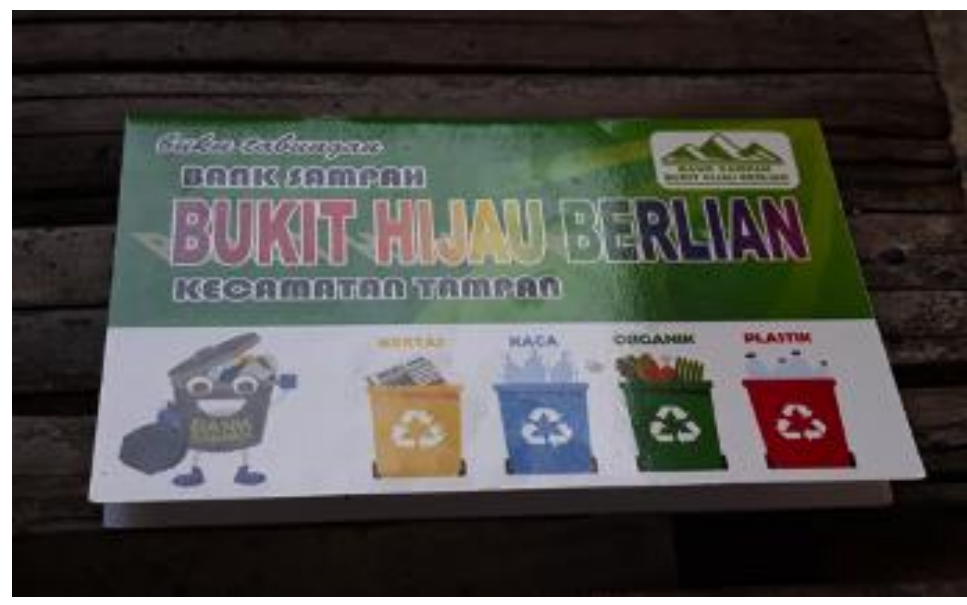

Gambar 2. Buku tabungan bank sampah

Buku tabungan bank sampah ini merupakan buku tabungan dari bank sampah induk Kecamatan Tampan yaitu Bukit Hijau Berlian, sedangkan pada gambar 3, menunjukkan hasil tabungan salah satu nasabah.

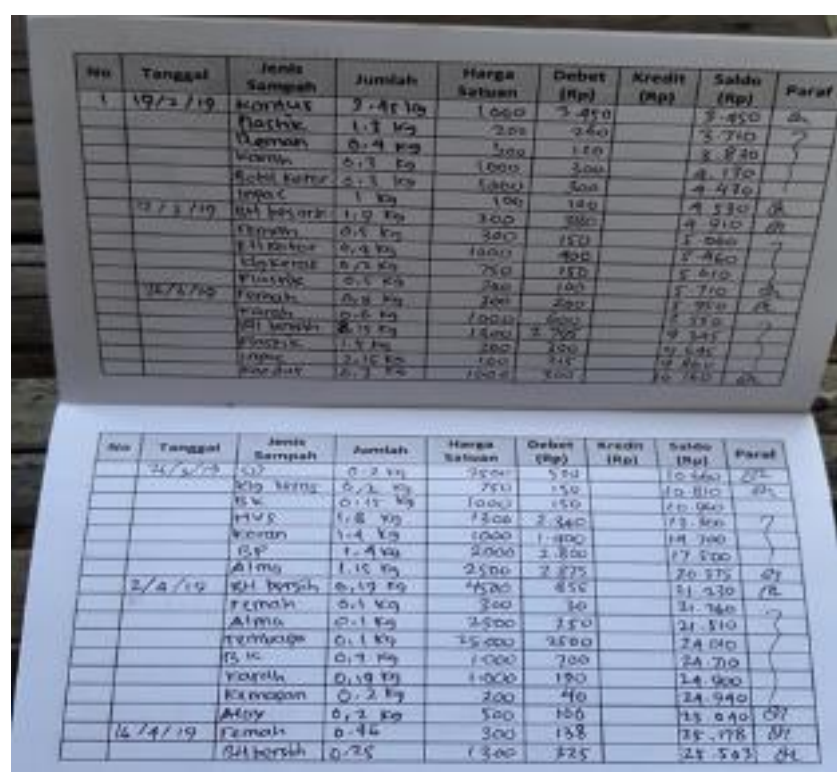

Gambar 3. Hasil tabungan nasabah

Keberadaan bank sampah memberikan kontribusi secara signifikan pada aspek lingkungan, ekonomi, serta sosial. Salah satu manfaat bank sampah yaitu membantu mengurangi volume sampah yang akan diangkut oleh armada pengangkut sampah di lingkungan RT/RW. Pengembangan dan keberlanjutan bank sampah berdampak positif pada aspek ekonomi, lingkungan dan sosial. Khususnya pada bank sampah Puri Berlian yang tergolong baru dan memerlukan pendampingan serta penyediaan sarana dan prasarana untuk keberlanjutannya. Salah satu nasabah bank sampah dengan wajah ceria mengantarkan sampahnya untuk ditabung seperti tampak pada gambar 5 . 


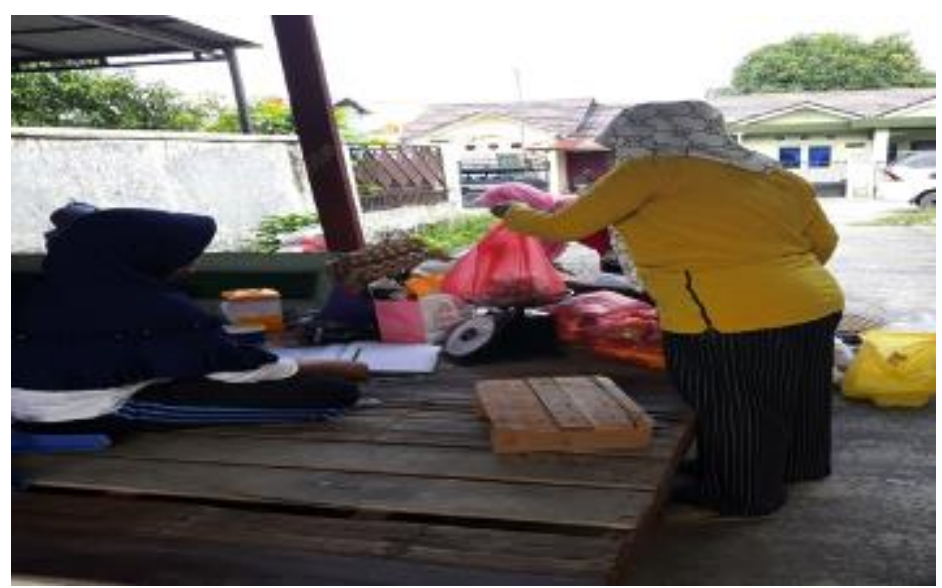

Gambar 4. Salah satu nasabah bank sampah Puri Berlian

\section{KESIMPULAN}

Kegiatan di bank sampah Puri Berlian telah berjalan kembali sejak diterapkannya new normal oleh pemerintah, penimbangan, pemilahan dan tabungan bank sampah kembali normal. Namun, mengingat kondisi pandemic Covid-19 di Kota Pekanbaru jumlah pasien terinfeksi Covid-19 terus meningkat dari waktu ke waktu menjadikan Kota Pekanbaru zona merah penyebaran virus Corona. Kecamatan Tampan dengan jumlah penduduk terbesar di Kota Pekanbaru menjadi daerah yang cukup rawan menjadi pusat penyebaran covid-19. Sehingga pemerintah memberlakukan PSBM (pembatasan sosial berskala mikro) di Kecamatan Tampan, tentunya hal ini juga berdampak pada pengembagan dan keberlanjutan kegiatan bank sampah.

\section{DAFTAR PUSTAKA}

Afriadi, Z., Yetti, H., Abdiana, A. 2019. Gambaran Pengelolaan Sampah Rumah Tangga melalui Bank Sampah di Kota Pekanbaru. Jurnal Penelitian Kesehatan Suara Forikes, 10.

Antin, T. 2019. Komunikasi Literasi Sampah dalam Medukung Pembangunan Berkelanjutan (Studi Komunikasi Literasi Sampah sebagai Respons Masyarakat dan Pemerintah Daerah Kabupaten Bantul 2008-2014). Universitas Gadjah mada, Yogyakarta.

BPS. 2020. Kecamatan Tampan dalam Angka 2019.

Dinas LHK Pekanbaru. 2019. Laporan Akuntabilitas Kinerja Instansi Pemerintah Dinas Lingkungan Hidup dan Kebersihan Kota Pekanbaru Tahun 2018.

Nasution, Z. 2002. Komunikasi pembangunan pengenalan teori dan penerapannya. PT. Raja Grafindo Persada, Jakarta. Republik Indonesia, P. 2008. Undang-Undang Nomor 18 tahun 2008 Tentang Pengelolaan Sampah.

Sucipto, C.D. 2012. Teknologi Pengolahan Daur Ulang Sampah. Gosyen Publishing, Yogyakarta.

Suriyani, L.D. 2020. Produksi Sampah dari Rumah Meningkat di Masa Pandemi Corona, Kok Bisa? [WWW Document]. Mongabay Environmental News. URL https://www.mongabay.co.id/2020/04/28/produksi-sampahdari-rumah-meningkat-di-masa-pandemi-corona-kok-bisa/ (accessed 10.3.20).

Suwenda, B. 2012. Bank Sampah (Kajian Teori dan Penerapannya). Pustaka Rihama, Yogyakarta. 